Dr. R. I. B. Francki) that the uracil analogue 2-thiouracil had very different effects on the rod-shaped tobacco mosaic virus and on the spherical turnip yellow mosaic virus. After tea, Dr. G. A. Nicholls, of New Zealand Forest Products, Ltd., took his audience on an illustrated tour of his firm's plant, and discussed the work of his laboratory in the fields of bark utilization, pulping, bleaching and turpentine refining. Dr. A. T. Wilson, of Victoria University of Wellington, then wound up the proceedings with a highly enter. taining exposition of his theories on the physical system in which life may have originated.
In the discussion of the way in which future meetings should be organized, there was general agreement that they should be kept as informal as possible, so that ideas could be aired and discussed before they had reached the stage of publication. It was also agreed that the meetings should be held at various laboratories in turn, so that in time everyone would have a first-hand knowledge of what everyone else was doing. Of the various time-intervals which were suggested, a year was most favoured, and Drs. McCree and Probine were asked to handle the arrangements for the next meeting. K. J. MCCREE

\title{
MEDICAL RESEARCH IN THE BRITISH CARIBBEAN
}

T HE sixth scientific meeting of the Standing Advisory Committee for Medical Research in the British Caribbean was held at the Marine Hotel, Bridgetown, Barbados, during April 10-13. Thirtyeight communications were delivered, and six were read by title only. Chairmen for the five sessions were Sir Harold Himsworth, Prof. T. H. Weller, Prof. A. C. Frazer, Dr. E. T. C. Spooner and Prof. E. K. Cruickshank.

The meeting was remarkable for the high standard of presentation, the diversity of subject-matter, and for the evidence which it offered of the stimulating effect of a research interest on all fields of medicine and its ancillary professions. The theme of the meeting-the impact of research on public healthwas chosen to be as nearly all-embracing as possible.

R. A. Irvine, C. Miller and L. S. Grant (Univ. Coll., West Indies) reviewed typhoid infection in Jamaica. During the period 1952-59, typhoid fever had affected chiefly the younger age groups, with a relapse-rate of 8 per cent and a case fatality of 5.8 per cent. M. T. Ashcroft (British Guiana) reported a steady decline in fatality of typhoid fever in British Guiana, partly due to improved water supply and partly to the introduction of chloramphenicol treatment. C. C. Nicholson and J. M. Ritchie (British Guiana) directed attention to imperfections still remaining in British Guiana water supplies. E. H. Back and S. E. Brooks (Univ. Coll., West Indies) analysed 134 cases of gastroenteritis in infants admitted to University College Hospital, Jamaica, and discussed prognosis. F. C. Ramsey (Barbados) described scarlet fever in Barbados, suggesting that the disease is less rare than it is said to have been. G. Bras, D. Watler and S. E. Brooks (Univ. Coll., West Indies) quoted figures from the Cancer Registry at University College Hospital to show that carcinoma of the cervix in Jamaica is responsible for more than 30 per cent of all malignancy in females. J. D. Arneaud (Trinidad) discussed drug resistance of tubercle bacilli isolated in Trinidad. K. D. B. Charlea (Jamaica) and L. S. Grant (Univ. Coll., West Indies) reviewed poliomyelitis in Jamaica with special reference to the epidemics of 1954, 1957 and 1960. J. S. R. Golding (Univ. Coll., West Indies) described the management of those disabled in a moderately severe epidemic of poliomyelitis, and demonstrated the necessity for a planned programme. L. Spence (Trinidad) gave an account of the distribution of Eastern equine encephalitis virus in Trinidad and British Guiana. In Trinidad, the virus has been isolated on six occasions from culicine mosquitoes; and in British Guiana from horses during an outbreak. In Trinidad, immunity has been demonstrated in humans, birds and poultry. L. S. Grant (Univ. Coll., West Indies) reported a survey of $Q$ fever antibodies in Jamaica, showing that this infection is not at present prevalent. W. G. Downs, L. H. Turner and A. E. Green (Trinidad) found 10 per cent of human sera from cases of undiagnosed fever in Trinidad agglutinated leptospiræ, and reported 17 isolations of leptospirse in culture. They directed attention to the lack of knowledge of the local ecology of leptospirosis. A. V. Wells (St. Lucia) described the successful eradication of malaria from St. Lucia. G. Giglioli (British Guiana) discussed the effect of malaria eradication in British Guiana on mortality from chronic nephritis. F. R. S. Kellett (Trinidad), as part of the malaria eradication plan in Trinidad, had used 'Baytex' (S 29493) as a spray, and showed that this insecticide is effective on various household pests including culicine mosquitoes. T. H. G. Aitken (Trinidad) discussed the ecology of Culex quinquefasciatus and its importance for public health in the Caribbean area as a vector of filaria, St. Louis encephalitis and Cache Valley fever. L. M. Burke (Jamaica) gave an account of the clinical features of poliomyelitis in Jamaica, as seen in a study of 309 cases admitted to Kingston Public Hospital during 1957-60. J. A. S. Hall (Jamaica) discussed the role of infection in a series of twenty cases of myelomatosis. E. H. Back and E. E. DePass (Univ. Coll., West Indies) considered rheumatic fever as seen in University College Hospital, Jamaica, during 1952-60, and described the beneficial effect of maintenance benzathine penicillin. F. M. McWatt (British Guiana) read an interesting paper on liver cirrhosis in cattle on the savannahs of British Guiana, where three species of Crotalaria have been identified. The cause of the disease has not been ascertained, but liver biopsies have shown that the fibrosis regresses at certain times of year or when the animals are moved to improved pastures. E. E. Ward and E. H. Back (Univ. Coll., West Indies) reported work on electrolyte disturbance in infantile gastroenteritis. T. Poon-King (Trinidad) gave an important account of electrocardiographic changes observed in patients stung by the Trinidad scorpion, Tityus trinitatis. The sting of this scorpion produces severe physiological disturbance and sometimes kills. Electrocardiographic abnormalities were found in 39 of 45 patients studied. E. E. Ward (Univ. Coll., West Indies) 
discussed $\gamma$-globulin-levels in Jamaicans; he found no racial differences, but levels were higher in those with chronic infections than in the healthy. R. A. Webb (Barbados) analysed 330 first admissions to the Barbados Mental Hospital, in which records of mental ill-health for the whole island have been kept for many years. Heredity was revealed as a more important etiological factor than environment. K. L. Standard (Barbados) presented an analysis of child mortality in Barbados, reporting a marked reduction in infant mortality over the past six years. Miss $G$. Shaw, L. S. Grant and A. A. Peat (Jamaica) gave an account of the statistics of communicable disease in Jamaica up to 1956. K. H. Uttley (Antigua) discussed mortality from tuberculosis in the negro population of Antigua over the past 100 years. B. Weinstein (British Guiana) reported a survey of diabetes among residents on the sugar estates of British Guiana. He found an overall incidence of 2.04 per cent and discussed etiological factors. $J$. Parker-Williams (Univ. Coll., West Indies) described a survey of abnormal hæmoglobin in Barbados, with special reference to the sickling gene. He compared Barbados with Jamaica in this respect, and discussed genetical implications. R. J. Gourlay (Univ. Coll., West Indies) described the incidence of certain worm infestations in Jamaica. Miss A. Walters and Mrs. G. Jordan (Barbados), two public health nurses in Barbados, presented a most interesting time-study of the work of public health nurses at three health centres in Barbados, showing that more time was spent on maintenance and records than on the treat. ment and care of patients. H. M. Beadnell (British Guiana) recounted eight years experience with injuries and workmen's compensation in the sugar estates of British Guiana. D. O. Gore (Univ. Coll., West Indies) gave a clinical and pathological account of the portal hypertension produced by 'veno-occlusive disease', and reported on six patients treated by establishing porto-caval shunts. F. F. Laband (Trinidad) gave an account, illustrated with colour slides, of four years experience of oral surgery in the San Fernando General Hospital, Trinidad. A. G. Leacock and R. K. Rowley (Barbados) reported the results of repairing inguinal hernias by the 'nylon darn' technique. J. A. B. Jones (Univ. Coll., West Indies) discussed some anatomical and pathological abnormalities of the elimentary tract as seen in Jamaica. Winston Adams (British Guiana) gave an account of the control of two malaria outbreaks in the interior of British Guiana, discussed the difficulties of control of Anopheles darlingi, the local malaria vector, and mentioned the programme of chloroquinized salt prophylaxis now in operation in this area. E. L. S. Robertson (Trinidad) showed a film demonstrating the surgical trestment of filaria lymphœdema.

Excellent arrangements were made for the meeting by Dr. Maurice Byer, director of Medical Services, Barbados, and his staff.

\section{HISTORY OF SCIENCES IN ANCIENT AND MEDIEVAL INDIA}

\begin{abstract}
A SYMPOSIUM on the "History of Sciences in Ancient and Medieval India" was held during August 4-5 at the Bose Institute, Calcutta, under the auspices of the National Institute of Sciences of India. The symposium was inaugurated by Dr. D. M. Bose, director of the Bose Institute. In his opening remarks, Dr. A. C. Ukil, convener of the symposium, referred to the importance the study of the history of sciences in India had assumed during recent years and the problems which the workers in the field have to face, especially in connexion with the source materials. The discrepancy of knowledge regarding chronology, he observed, constituted a serious difficulty which should engage the attention of the research workers in the subject. Regarding the investigations already made, which he termed secondary sources, the attitude taken in the past and points of view expressed required in many instances to be re-examined and re-evaluated.
\end{abstract}

Thirty-five papers were received for the symposium of which twenty-three were read and discussed. In his paper on the social and international relations in the development of science, Dr. R. C. Majumdar pointed out that there is direct evidence to show that scholars from India visited Western countries and taught the people there medical science, astrology, astronomy, algebra and arithmetic as known to India and also indirect evidence of intermational exchange of scientific knowledge between India and foreign countries. European scholars have generally held that in scientific matters it was India that must have borrowed from Western countries. But with the advance in knowledge of history, he observed, it was difficult to subscribe to this viow of one-way traffic.
This observation was further substantiated in the paper by Sri S. N. Sen, who furnished archæological and epigraphic examples and also case-histories such as the transmission of the knowledge of the decimal place-value notation, and some medical and astronomical ideas.

In biology, health and medicine, Dr. N. H. Keswani discussed the concepts of generation, reproduction, evolution and human development as found in the writings of Indian scholars of the ancient and medieval period. He noted that the results of their observations, unaided by microscopes and modern appliances, approached in accuracy those of modern work, especially in the field of embryology. Zoological knowledge in the works of $K_{\dot{a}}$ lidasa formed the subject of two papers by Sri C. S. Gupta and Sri B. Rama Rao, while Dr. S. S. Misra gave a review of the development of medical sciences in India.

On Indian chemistry, Dr. B. V. Subbarayappa's paper dealing with Indian atomism showed independent development of the atomic concept of matter in the Hindu, Buddhist and Jaina literature and the difference between the Indian ideas and those propounded by the Greek acholars headed by Democritus and Leucippus. Dr. S. P. Raychaudhuri and Dr. A. K. Bhattacharyya dealt with the agricultural practices and soil science in ancient India.

The geographical ideas of the Hindus were presented by Dr. S. M. Ali. Besides these were the discussions on the development of mathematical series in India after Bhaskara II, Bhaskara's works on differential and integral calculus, science and society in the Arthasastra and the Ramayana, and the general scientific contents in the Vedic literature. S. N. S. 